\title{
Exploring the Effect of Peer Feedback and the Students' Perceptions of the Feedback on Students' Writing Skill
}

\author{
Rias Wita Suryani, Yenni Rozimela, Desvalini Anwar \\ Faculty of Languages and Art, Universitas Negeri Padang, Padang, Indonesia \\ Email address: \\ riaswitaxxx@gmail.com (R.W. Suryani),yennirozi@gmail.com (Y. Rozimela), desvalinianwar@yahoo.com (D. Anwar)
}

To cite this article:

Rias Wita Suryani, Yenni Rozimela, Desvalini Anwar. Exploring the Effect of Peer Feedback and the Students' Perceptions of the Feedback on Students' Writing Skill. International Journal of Secondary Education. Vol. 7, No. 4, 2019, pp. 116-121.

doi: $10.11648 /$ j.ijsedu.20190704.14

Received: November 14, 2019; Accepted: December 9, 2019; Published: December 31, 2019

\begin{abstract}
This study was aimed to investigate the effect of peer feedback on students' writing skill and the students' perceptions on the practice of peer feedback. The study adopted mixed methods research design. It involved 70 eleventh grade students in two intact classes at one public senior high school in West Sumatra, Indonesia. The students were given different types of treatment: the students from experimental class were given feedback from peers, and those from control class were given feedback from teacher. The study lasted 8 weeks. The data were collected through post-test and semi-structured interview. The post-test was used to obtain students' writing scores and semi-structure interview to know their perception on the peer feedback. Findings of the study indicated that the students that were given peer feedback had better writing skill than those were given teacher feedback. This study also shows that the students had positive perceptions towards writing. They liked using this strategy because it made writing process become less stressful. However, there were also some students who valued teacher's feedback more highly than the peer feedback. Those students believed that grammatical accuracy was more possible to be achieved through teacher feedback than through peer feedback because they thought that their peers had inadequate grammar knowledge.
\end{abstract}

Keywords: Peer Feedback, Teacher Feedback, Students' Writing Skill

\section{Introduction}

Giving feedback in the writing process is important in order to improve students' writing quality [1]. It is equal to the importance of revising or editing in the writing process. Feedback given is as a source of information about the students' strengths and weaknesses on their writing to do improvement. It has become a concern of many researchers in second or foreign language writing $[2,3]$. Through feedback given, students are expected to be able to focus and concentrate more on what is being learned. Furthermore, feedback makes students more aware of their strengths and weaknesses in writing so it is expected that they can use the strengths to overcome the weaknesses by understanding the feedback given.

Traditionally, feedback has been seen to be the exclusive responsibility of teachers [4]. Providing effective feedback is an important task for English writing teachers, since it is contributed to the improvement of the students' writing [5-7], although it is often neglected and misunderstood by students [2]. Teacher feedback has also been criticized for being product oriented as it generally occurs at the end of a writing assignment [8]. In addition, teacher feedback is a one-way passive process for the students and does not develop their autonomous output skills [9]. Therefore, it is important for the English writing teacher to consider an effective way to give feedback during the writing process.

Currently, peer feedback has also been shown to help improve students' writing and has become a regular practice in classrooms advocating a process writing approach [10, 11]. Indeed, it has been conducted to improve students' writing $[12,13]$. Then, peer feedback has positive effects on students' writing process and product [14]. Also, students often pay more attention to peer feedback due to its social dimension. Perhaps they feel less threatened by their peers rather than their teacher [15]. Other researchers consider peer feedback as complementary to teacher feedback [11]. In addition, peer feedback enhances the content, organization, 
and vocabulary of the students' writing [16]. Also, peer feedback offers students an opportunity for social interaction and improvement of their writing skills, critical thinking, confidence, creativity, motivation, and assignments [17]. Moreover, students enhance their writing skills from the comments provided by their peer in terms of content or critical thinking, surface structure/ grammatical aspects [18]. From these findings, it can be concluded that the implementation of peer feedback gives a positive effect on students' writing skill.

However, conflicting findings also have been reported on its effectiveness and helpfulness. Some students were even reported to be unsure of their own power as competent readers while reading others' writings [19]. Also, peer feedback could lead improvement of students' writing with respect to accuracy, but no significant differences were found with respect to grammatical and lexical complexity [19]. Thus, of these findings, peer feedback in the writing classroom still presents problems to solve. Despite peer feedback yields benefits and drawbacks as alternately reported by researchers, the practice of peer feedback has been widely applied in writing class. Therefore, the studies on peer feedback need further exploration and that more studies are still needed in different contexts to contribute to understanding of the issue of peer feedback in teaching writing. This study was aimed to investigate the effect of using peer feedback on students' writing skill and their perception in implementing peer feedback.

\section{Literature Review}

Traditionally, teacher is frequently referred to as the ones who could give feedback to students' writing. Studies on teacher feedback have mainly focused on the nature of the comments provided by the teachers, the resulting revisions and the students' reactions to the comments. The findings of studies on teacher feedback also point to some weak areas of traditional teacher feedback and show that in fact teacher feedback is not as infallible as it is commonly believed by students and teachers alike. Although most teacher feedback tends to be focused on overt correction, a body of research exists which lends support to the idea that corrective feedback does not improve students' writing over time [20]. Moreover, being primarily focused on language specific errors, teacher feedback has often been criticized for being confusing, arbitrary and inaccessible [21]. When giving feedback, teacher's attitude is a key component which affects results considerably. For example, if only one type of feedback is used in excess, e.g. if a student is continuously criticized, it may lead to frustration and demotivation [22]. Similarly, too much error correction can be discouraging for the students [23]. Thus, rather than relying only on teacher feedback, it is important for English writing teacher to considers alternative way in giving feedback on students' writing.

Currently, peer feedback advocated by many researchers has figured prominently in writing process [24]. Peer feedback is the use of learners as sources of information for each other in such a way that learners assume roles and responsibilities normally taken on by a formally trained teacher, tutor, or editor in commenting on and critiquing each other drafts in both written and oral formats in the process of writing [25]. In other words, peer feedback supports process writing with a focus on drafting and revision and enables students to get multiple feedback (e.g. from a teacher, a peer, and from oneself) across various drafts. Most importantly, it builds audience awareness; helps make reading-writing connections; and builds better content, linguistically, semantically and rhetorically through multiple exposures of a draft text.

There are various reasons that account for the popularity of using peer feedback in writing classes: (1) students find peers feedback a valuable source of information and a supplement to any teacher feedback [26], (2) students find teacher feedback too general, vague, incomprehensible, and/or authoritative compared to feedback from peers which is perceived to be more specific [21], (3) it helps teachers "to escape from the tyranny of red pen and explore an activity that can complement her own feedback to her students' writing, collaborative peer feedback is a potentially rewarding option" [27], (4) the response and revision process contributes to more effective revision and critical reading [27], (5) it provides a real audience for students' writings [27].

In line with the above opinions, there are some practical benefits of peer feedback: (1) Students gain confidence, perspective, and critical thinking skills from being able to read texts by their peers writing on similar tasks; (2) Students get more feedback on their writing than they could from the teacher alone; (3) Students get feedback from a more diverse audience bringing multiple perspectives; (4) Students receive feedback from non-expert readers on ways in which their texts are unclear as to ideas and language; (5) peer feedback activities build a sense of classroom community [3].

Other advantages of peer feedback are: First, for students as authors: (1) Refines their ideas as a result of the feedback they receive; (2) Focus on writing as a process that emphasizes editing and revisions; (3) Develops a better sense of audience; (4) Improves their work before it is submitted for grading; (5) They are motivated to produce higher-quality work, since they know their peers will be critiquing it. Second, for the students as reviewers: (1) Gain insights for their own work from reading the assignments of others; (2) See other approaches to an assignment or other perspectives to an issue; (3) Become familiar with important aspects of the assignment as they use the rubric or criteria to perform their review; (4) Improve their ability to read a paper critically; (5) Strengthen their communication skills, especially in respect to critiquing and providing feedback; (6) Gain knowledge of a wider variety of course topics [28].

In contrast, there are some previous studies that brought different findings. If students do not have the correction skill, peer-feedback will be slow and less effective, which in turn can lead to a common problem of unintelligibility between 
the reviewers and those reviewed [29]. Moreover, some students who have been mainly in teacher-fronted classes may feel it is the job of the teacher to correct and the peer may not provide the same good feedback as the teacher whom students often prefer [11]. The proficiency gap is another problem, while low proficient students are doing peer feedback with their more proficient peers; and finally, students might feel reluctant to show their writings to others owing to fear caused by their incapability [30]. Thus, those study results in this area are inconclusive and are still debated among researchers.

\section{Methodology}

This study was a small scale mixed methods study because it used qualitative and quantitative research and methods for collecting and analyzing data in order to understand a research problem. It involved 70 eleventh grade students in two intact classes at one public senior high school in West Sumatra, Indonesia. One class consisted of 35 students and was treated as the experimental class. The second class also consisted of 35 students and was treated as the control class. In the experimental class, the students were given peer feedback; in the control class, the students were given teacher feedback.

In order to collect data, a writing test and a semi-structured interview were used. The writing test was administered at the end of the research in order to measure students' writing ability. The writing test consisted of an instruction where the students wrote an Explanation text based on the topics given. There were three alternative topics offered. The students chose one of the topics to write their Explanation text. The test was about 100-150 words in 90 minutes on the available time for one meeting. Then, semi-structured interview was obtained to elicit students' perception on the implementation of peer feedback. The interview consisted of two questions: (1) Aspects of the peer feedback experience that students liked the most; and (2) Aspects of the peer feedback experience that students liked least.

\section{Findings and Discussions}

\subsection{Findings}

Findings are presented with reference to the two research questions which formed the focus of this study. This study used t-test formula for the first research question in order to know the effects of peer feedback on students' writing. Then, for second research question, the semi-structured interview was used to know students' perception on implementation of peer feedback.

What is the effect of peer feedback on students' writing skill?

To answer the first research question, independent sample test was run by using SPSS version 24. The results of the independent $\mathrm{t}$-test is presented in the table 1 below:

Table 1. The Summary of T-test Analysis of Writing Test in Experimental and Control Class.

\begin{tabular}{lll}
\hline \multirow{2}{*}{ Data } & Peer Feedback & Teacher Feedback \\
\cline { 2 - 3 } & $\mathrm{N}: 35$ & $\mathrm{~N}: 35$ \\
$\mathrm{t}_{\text {observed }}$ & $\mu: 75.29$ & $\mu: 71.91$ \\
$\mathrm{t}_{\text {table }}$ & 2.080 & \\
Conclusion & 1.667 & \\
\hline
\end{tabular}

From the table above, it can be concluded that the result of the T-test analysis indicates that the value of $t_{\text {observed }}$ is 2.080 which higher than $t_{\text {table }} 1.667$ with the level of significance 0.05 . It means that the alternative hypothesis $\left(\mathrm{H}_{\mathrm{a}}\right)$ is accepted and the null hypothesis $\left(\mathrm{H}_{\mathrm{o}}\right)$ is rejected. It means that the students who were taught by using peer feedback had better writing skill than those who were taught by using teacher feedback. Moreover, the mean score of the students who were taught by using peer feedback (75.29) is higher than those who were taught by using teacher feedback (71.91). Thus, it can be concluded that teaching writing by using peer feedback give better result than using teacher feedback. This is happened because of it provides useful feedback and by reading others' writing as critical readers, students could become more critical readers and revisers of their own writing.

What is the students' perception in implementing peer feedback?

In order to find out the perceptions of the students toward peer feedback, the semi-structured interviews were content analyzed. The students in experimental class $(\mathrm{N}=20)$ were interview. There were two general questions included in the interview intended to answer the two research objectives.

The first question was "What are some of the things that you liked most about the peer feedback experience?" An analysis of students' responses to this question resulted in three aspects: (1) getting a different perspective on and a real audience for one's essay, "it is always nice to have someone else read your work and point out aspects/points you wouldn't have noticed yourself"; (2) getting new ideas, "the discussion of the topic gave a better understanding of the views of other people"; and (3) being able to notice one's own mistakes, "it allows you to see the problems in your own paper while you see them in another's paper". As shown in the table 2 below, the percentages of students' perception referring to each aspects regarding peer feedback experience that they liked the most. These results indicated that students' primary support for peer feedback involved the benefits obtained from a new perspective (i.e., new perspectives and new ideas from others and self). 
Table 2. The percentage of peer feedback perception related to aspects students liked the most.

\begin{tabular}{lll}
\hline Aspects liked the most & Agree & Disagree \\
\hline Getting a different perspective on and real audience for one's essay & $(16) 80 \%$ & $(4) 20 \%$ \\
Being able to notice one's own mistakes & $(12) 60 \%$ & $(8) 40 \%$ \\
Getting new ideas & (14) $70 \%$ & $(6) 30 \%$ \\
\hline
\end{tabular}

The second question was "What are some of the things that you liked least about the peer feedback experience?" An analysis of students' responses to this question resulted in three aspects: (1) lengthy face-to-face session, "talking for fifteen minutes per essay was a little long"; (2) feeling unsure about accuracy of feedback provided and received, "I am afraid I will give them wrong or incorrect advice"; and (3) writing a formal critique, "I didn't like having to write the feedback". As shown in the table 3 below, the percentages of students' perception referring to each aspects regarding peer feedback experience that they liked least. These results indicated that students' primary concerns regarding peer feedback included both structural concerns (e.g., length of feedback sessions) and proficiency concerns (e.g., accuracy of feedback given and received).

Table 3. The percentage of peer feedback perception related to the aspects that the students liked the least.

\begin{tabular}{lll}
\hline Aspects liked the least & Agree & Disagree \\
\hline Feeling unsure about the accuracy of feedback provided and received & $(17) 85 \%$ & $(3) 10 \%$ \\
Lengthy face-to-face session & $(15) 75 \%$ & $(5) 25 \%$ \\
Writing a formal critique & $(16) 80 \%$ & (4) $20 \%$ \\
\hline
\end{tabular}

\subsection{Discussion}

The effect of peer feedback on students' writing skill

Based on the findings, it was found that the treatment which is given to the experimental class by using peer feedback strategy to improve students' writing skill is successful. There are some factors which make peer feedback was better than teacher feedback this research. First, peer feedback demanded students work in team. They have responsibility to help their friends to understand the material by giving them feedback. Students must communicate with their friends once they could not understand the feedback. Second, in peer feedback they will have to comprehend their peer's work carefully to give the feedback. At that time, unconsciously, they study by themselves and it also grow their motivation to know more. Third, peer feedback demands students to be active. It also supports the situation in the class. Learning a language cannot be understood only by explanation. They should practice it frequently. In most classes, the students who passively learn could not understand the material well. Yet, learning by doing is still become the key to comprehend the material well.

However, even though this strategy focus on students as the center of learning, teacher's explanation is still needed to make them easily understand about what they should assess their peers' writing. The students' participation is effective if the teacher give clear explanation about the students' roles and job description and the procedure in doing peer feedback. Another discovery of this research is following stages of writing is very important as includes feedback in some stages of writing could help the students to understand how to write effectively.

Moreover, peer feedback is also one of cooperative learning strategies. By working collaboratively, the students will not only see their work from their perspective but also sees from another perspective through their peer [27].
Therefore, peer feedback is better than teacher feedback in engaging students in the process of sharing their ideas and receiving as well as offering constructive comments and suggestions for improving writing. The finding of this research is also supported by a research about The Impact of Peer Feedback on Improving the Writing Skills among Hebron University Students. The result of the study indicated that students viewed peer feedback as a worthwhile experiences, it offered an opportunity for social interaction. It also improves students' writing skill. From the discussion above, it can be concluded that peer feedback helps the students to improve their writing skill [17]. Thus, it is an appropriate strategy in helping students to increase their writing skill.

Students'perception on the practice of peer feedback

Based on the interview responses, the majority of students had positive perception towards the use of peer feedback in writing process. Most of the students thought receiving and giving feedback to their friends decreased their anxiety in writing. They know that making mistakes is a part of learning and they make some common mistakes. They collaborate with each other to overcome the mistakes while writing. These are the reasons for this assumption. These reasons make the writing process less stressful and anxious according to the students.

Furthermore, previous study found that students assign value to the peer feedback experience in terms of its contribution to providing a real audience, different perspectives, and raising metacognitive awareness [11]. The results of the present study echo these findings as peer feedback perceiving students expressed that getting a different perspective on their essay and a different audience were some of the aspects of the experience they liked the most. In addition, students expressed that participating in the experience helped them notice their own mistakes, thus helping to enhance their metacognitive awareness. 
In contrast, there were some aspects of the experience that students did not particularly like. Students expressed that they feeling unsure about the accuracy of feedback provided and received and the face-to-face session was lengthy. Similar to some of the findings in the literature, students identified their lack of confidence in providing accurate feedback as an issue, due to the fact that both students were still developing their language proficiency. Some students agreed this assumption because their friends did not have the capacity to give feedback and did not want to show their writings to someone else [31].

\section{Conclusion}

The result of this study unveiled that the students who were taught by using peer feedback had better writing skill than those who were taught by using teacher feedback. This happened because of it provides useful feedback and by reading others' writing as critical readers, students could become more critical readers and revisers of their own writing. Apart from the main result, this study also offered some evidence that peer feedback was not effective in dealing with grammatical accuracy, but teacher feedback was found to be effective for grammatical accuracy because of the students' inadequate grammar knowledge. So for grammatical errors, students favored teacher feedback than peer feedback. Some recommendations are directed to English teachers and future researchers. For English teachers, it is recommended that they need to consider applying and implementing the combined strategies (peer feedback and teacher feedback) in the teaching writing. Also, teacher should be well trained in implementing peer feedback. For further researchers, it is suggested that they investigate the effect of peer feedback in different moderator variable, text types and sample.

\section{Acknowledgements}

I would like to acknowledge my indebtedness and render my warmest thanks to Prof. Dra. Yenni Rozimela, M. Ed, Ph. D and Desvalini Anwar, S. S, M. Hum, Ph. D who have given valuable advice, meaningful contribution and guidance in accomplishing this research. It is her pleasure to work under their guidance.

\section{References}

[1] Brown, H. D. (2001). Teaching by Principle and Interactive Approach to language pedagogy. New York: Longman Inc.

[2] Bitchener, J., Young, S., \& Cameron, D. (2005). The effect of different types of corrective feedback on ESL student writing. Journal of Second Language Writing, 14, pp. 191-205.

[3] Ferris, D. R. (2005). Respond to students writing: Implications for second language students. Mahwah, N. J.: Lawrence Erlbaum Associates.

[4] Fallows, S., \& Chandramohan, B. (2001). Multiple approaches to assessment: reflections on use of tutor, peer and selfassessment. Teaching in Higher Education, 6 (2), pp. 229-246.

[5] Hyland, F., \& Hyland, K. (2001). Sugaring the pill: Praise and criticism in written feedback. Journal of Second Language Writing, 10, pp. 185-212.

[6] Ferris, D. R. (2006). Does error feedback help student writers? New evidence on the short- and long-term effects of error correction. In K. Hyland \& F. Hyland (Eds.), Feedback in second language writing: Contexts and issues (pp. 81-104). Cambridge: Cambridge University Press.

[7] Goldstein, J. (2004). Making sense of distributed leadership: The case of peer assistance and review. Educational Evaluation and Policy Analysis, 26 (2), pp. 173-197.

[8] Yang, M., Badger, R., \& Yu, Z. (2006). A comparative study of peer and teacher feedback in a Chinese EFL writing class. Journal of Second Language Writing, 15, pp. 79-200.

[9] Hojeij, Z. \& Hurley, Z. (2017). The triple flip: Using technology for peer and self-editing of writing. International Journal for the Scholarship of Teaching and Learning, 11 (1), pp. 655-678.

[10] Min, H.-T. (2006). The effects of trained peer review on EFL students' revision types and writing quality. Journal of Second Language Writing, 15 (2), pp. 118-141.

[11] Tsui, A., \& Ng, M. (2000). Do secondary L2 writers benefit from peer comments? Journal of Second Language Writing, 9 (2), pp. 147-170.

[12] Liu, N. F., \& Carless, D. (2006). Peer feedback: The learning element of peer assessment. Teaching in Higher Education, 11 (3), pp. 279-290.

[13] Rieber, L. J. (2006). Using peer review to improve student writing in business courses. Journal of Education for Business. 81 (6), pp. 322-326.

[14] Lundstrom, K., \& Baker, W. (2009). To give is better than to receive: The benefits of peer review to the reviewer's own writing. Journal of Second Language Writing, 18 (1), pp. 30-43.

[15] Falchikov, N. (2005). Improving Assessment Through Student Involvement: Practical Solutions for Aiding Learning in Higher And Further Education. London: Routledge.

[16] Lee, C \& Shzk, N. (2010). Written peer feedback by EFL students. Komaba Journal of English Education.

[17] Farrah, M. (2012). The Impact of Peer Feedback on Improving the Writing Skills among Hebron University Students. An - Najah Univ. J. Res. (Humanities). Vol. 26 (1) pp. 180-210.

[18] Srichanyachon, N. (2011). A comparative study of three revision method in EFL Writing. Barcelona Academic European Conference: Thailand.

[19] Gielen, S., Tops, L., Dochy, F. Onghena, P., \& Smeets, S. (2010). A comparative study of peer and teacher feedback and of various peer feedback forms in a secondary school writing curriculum. British Educational Research Journal, 36 (1), pp. $143-162$.

[20] Lu, R., \& Bol, L. (2007). A comparison of anonymous versus identifiable e-peer review on college student writing performance and the extent of critical feedback. Journal of Interactive Online Learning, 6 (2), pp. 100-115. 
[21] Zamel, V. (1985). Responding to student writing. TESOL Quarterly, 19: pp. 79-101.

[22] Silver, R. \& Lee, S. (2007). What does it take to make a change? Teacher feedback and student revisions. English Teaching: Practice and Critique, pp. 25-49.

[23] Ravichandran, V. (2002). Responding to Student Writing: Motivate, Not Criticise. GEMA Online Journal of Language Studies.

[24] Shehadeh, A. (2011). Effects and students' perceptions of Collaborative writing in L2. Journal of Second Language Writing, 20 (4), 286-305.

[25] Hansen, J. G. and Liu, J. (2005) Guiding Principles for Effective Peer Response. ELT Journal, 59, pp. 31-38.

[26] Hu. (2005). Using peer feedback with Chinese ESL student writers. Language Teaching Research, 9 (2005), pp. 321-342.
[27] Rollinson, P. (2005). Using Peer Feedback in the ESL Writing Class. ELT Journal, 59 (1): pp. 23-30.

[28] Liu J. \& Hansen, J. G. (2002). Peer Response in Second Language Writing Classrooms. Ann Arbor, MI: University of Michigan Press.

[29] Riddle, D. (2003). Teaching English as a foreign/second language. London: Teach Yourself.

[30] Riddiford, N. (2006). Collaborative error correction: How does it work? Prospect, 2 (13), 26-37.

[31] Carson, J. G., \& Nelson, G. L. (1996). Chinese students' perceptions of ESL Peer Response Group Interaction. Journal of Second Language Writing, 5 (1), pp. 1-19. 